« Favāyed-e adabī-e ketāb-e "TārīH-e dāmpezeškī va pezeškī”(-e İrān) », Našr-e Dānešs, 17, 3 (1379/2000), pp. 56-60.

\title{
Charles-Henri de Fouchécour
}

\section{(2) OpenEdition \\ 1 Journals}

\section{Édition électronique}

URL : http://journals.openedition.org/abstractairanica/35625

DOI : 10.4000/abstractairanica.35625

ISSN : 1961-960X

Éditeur :

CNRS (UMR 7528 Mondes iraniens et indiens), Éditions de l'IFRI

\section{Édition imprimée}

Date de publication : 15 mai 2002

ISSN : 0240-8910

\section{Référence électronique}

Charles-Henri de Fouchécour, « "Favāyed-e adabī-e ketāb-e "Tārīhn-e dāmpezeškī va pezeškī"(-e Īrān) », Našr-e Dāneš, 17, 3 (1379/2000), pp. 56-60. », Abstracta Iranica [En ligne], Volume 23 | 2002, document 238, mis en ligne le 08 février 2010, consulté le 25 septembre 2020. URL : http://

journals.openedition.org/abstractairanica/35625; DOI : https://doi.org/10.4000/abstractairanica. 35625

Ce document a été généré automatiquement le 25 septembre 2020.

Tous droits réservés 


\title{
« Favāyed-e adabī-e ketāb-e "TārīH̆- e dāmpezeškī va pezeškī”(-e İrān) », Našr-e Dāneš, 17, 3 (1379/2000), pp. 56-60.
}

\author{
Charles-Henri de Fouchécour
}

L'auteur s'attache à un chapitre du premier tome de l'ouvrage de Hasan TājbaHšs (2 tomes, Tehrān, 1372/1993 et 1375/1996), sur l'histoire de la science vétérinaire et de la médecine. Il montre la richesse d'information de l'ouvrage sur des sujets divers, comme les augures, les prières de guérison, les pratiques «magiques » qui étaient en fait le recours à des procédés naturels, etc. Le tout, tiré des textes persans, prose et poésie d'époque classique. Une mine de renseignements à rassembler à travers les deux tomes de Ḥasan TājbaȞš.

\section{INDEX}

Thèmes : 10. Histoire des Sciences et des Techniques

\section{AUTEURS}

\section{CHARLES-HENRI DE FOUCHÉCOUR}

Sorbonne Nouvelle - Paris III 